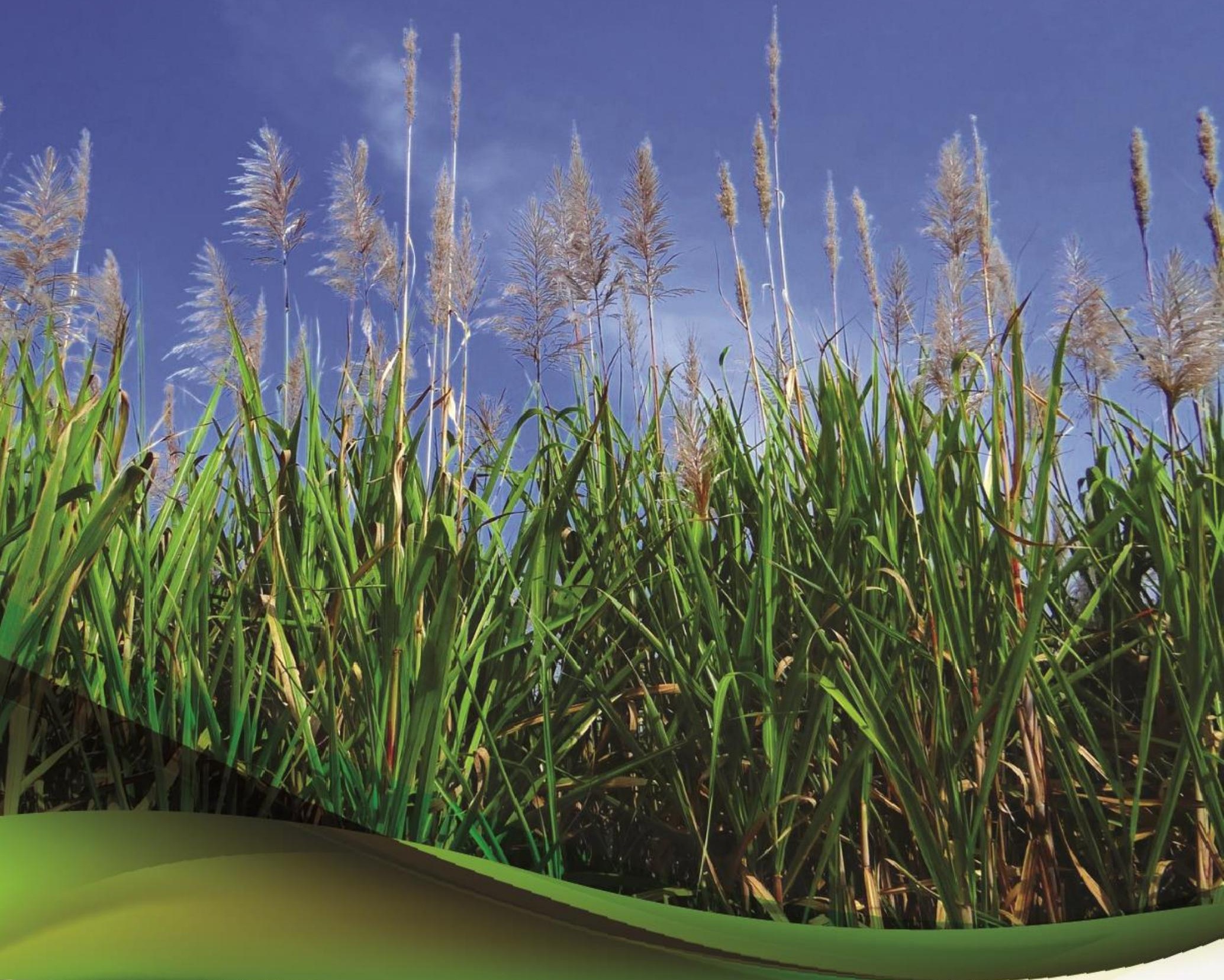

Pretreatment of sugarcane top leaves by ozonation as a promotion of susceptibility to hidrolysis

Pré-tratamento de ponteiro de cana de açúcar por ozonização como promoção da suceptibilidade à hidrolise

Felipe Iwagaki Braga OGANDO, Juliana Aparecida de Souza SARTORI,

Nathália Torres Corrêa MAGRI e Claudio Lima de AGUIAR 


\section{Pretreatment of sugarcane top leaves by ozonation as a promotion of susceptibility to hidrolysis}

\section{Pré-tratamento de ponteiro de cana de açúcar por ozonização como promoção da suceptibilidade à hidrolise}

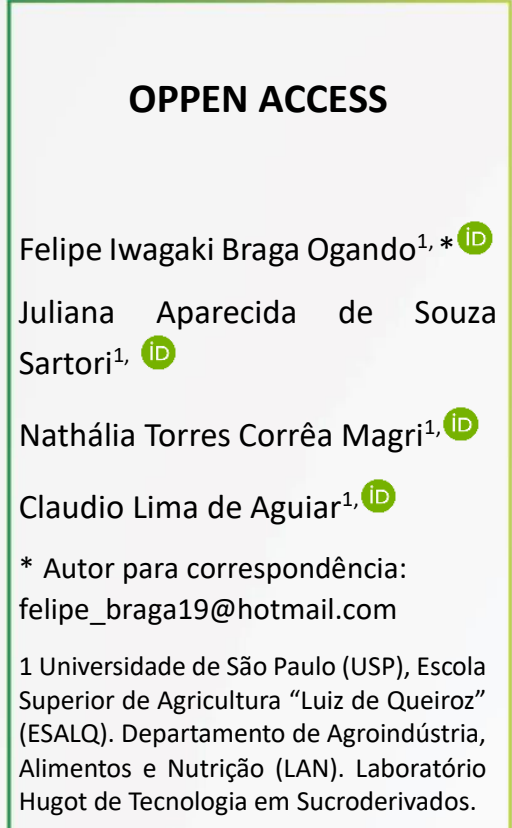

\section{Additional information}

Received: 09/06/2016

Accept: $12 / 11 / 2016$

Published: $12 / 20 / 2016$

Editor:

Victor Hugo Gomes Sales

Federal Institute of Amapá. Macapá, AP. jbfs@ifap.edu.br

\section{Double blind peer review}

Reviews process

Prot. 1192016R01 (Brasil)

Prot. 1192016R02 (Brasil)

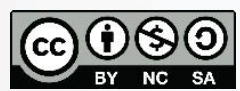

JBFS all rights

Copyright: (C) 2016

\begin{abstract}
ID JBFS1192016
DOI 10.18067/jbfs.v3i4.119

\section{ABSTRACT}

Studies about Ozone $\left(\mathrm{O}_{3}\right)$ application in sugarcane residues for ethanol production are ongoing. This study was undertaken to evaluate the use of ozone as a pretreatment to facilitate hydrolysis of sugarcane top leaves. In the first experimentation, sugarcane top leaves were subjected to ozone (62.37 $\mathrm{mg} \mathrm{O}_{3} \mathrm{~min}^{-1}$ over a three hour period) and water only (control). Following ozonation, the material was separated into a liquid and solid fraction. The analysis of liquid fraction showed that phenolic concentration and soluble solids did not vary. However, there was a decrease in $\mathrm{pH}$ and an increase in reducing sugars. This treatment increased saccharification. During the second treatment, ozone was added by direct infusion in a suspension of sugarcane top leaves and distilled water at a ratio of 1:10 $\left(w . v^{-1}\right)$. Additionally, the lignocellulosic analysis showed a positive relationship between the dose of ozone and decomposition of lignin and an increase in the proportion of cellulose and hemicellulose in the material. All aspects are good signs for the use of ozone in pretreatment of lignocelullosic feedstocks.
\end{abstract}

Keywords: Ozone, saccharification, lignocelullosic feedstocks.

\section{RESUMO}

Estudos sobre a aplicação de ozônio $\left(\mathrm{O}_{3}\right)$ nos resíduos de cana-de-açúcar para produção de etanol estão em andamento. Esse estudo foi empreendido para avaliar o uso de ozônio como um pré-tratamento para facilitar a hidrólise de ponteiros de cana-de-açúcar. No primeiro experimento, os ponteiros de cana-de-açúcar foram submetidos ao ozônio

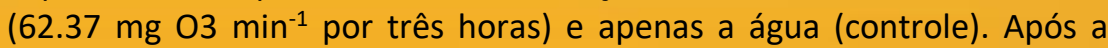
ozonização, o material foi separado em uma frações líquida e sólida. As análises da fração líquida mostraram que a concentração de fenólicos e sólidos solúveis não variaram. Entretanto, houve um decréscimo no pH e um aumento nos açúcares redutores. Esse tratamento aumentou a sacarificação. Durante o segundo tratamento, ozônio foi adicionado por infusão direta na suspensão de ponteiros de cana-de-açúcar com água destilada na razão de 1:10 $\left(\mathrm{m}^{\mathrm{v}} \mathrm{v}^{-1}\right)$. Adicionalmente, as análises mostraram uma relação positiva entre a dose de ozônio e a decomposição de lignina e um aumento na proporção de celulose e hemicelulose do material. Todos os aspectos são bons sinais para o uso de ozônio no pré-tratamento de materiais lignocelulósicos.

Palavras-chave: Ozônio, sacarificação, matéria-prima lignocelulósica. 


\section{INTRODUCTION}

Biofuel production from lignocellulosic biomass consists of three stages. ${ }^{1,2}$ These include harvest and transportation of biomass, breakdown of cell wall polymers into sugars and lignin by pretreatment and acidic or enzymatic saccharification, and conversion of sugars to biofuels using fermentation. Biomass recalcitrance to saccharification is a major obstacle to cost-efficient production of biofuels from lignocellulosic biomass. An increase in biomass saccharification efficiency can be achieved by using pretreatments to overcome recalcitrance and improve biofuel production. ${ }^{3}$

Pretreatment methods include physical (combination of chipping, grinding, milling, and compression) and chemical (concentrated and diluted acids, solvents and advanced oxidative process - AOP) treatments. ${ }^{47}$ Ozone is an example of $\mathrm{AOP}$ and the degradation of lignocellulosic biomass using $\mathrm{O}_{3}$ is mainly limited to lignin with a slight effect on hemicellulose and no effect on cellulose. Vidal and Molinier ${ }^{8}$ reported that pretreatment with ozone has advantages including effective removal of lignin, no production of toxic wastes, and the ability for the reactions to be performed at room temperature and pressure. In addition, ozonation offers the ability to degrade lignin and produce soluble compounds with lower molecular weight. ${ }^{9}$ García-Cubero et al. ${ }^{9}$ also showed that use of ozone reduced acid insoluble lignin in cereal straw and increased acid soluble lignin, thereby making it more accessible to enzyme hydrolysis and ozonation also reduces the formation of degradation products that may interfere with subsequent hydrolysis and fermentation stages. According to Kojima and Yoon, ${ }^{10}$ ozonation has been accepted as a viable option for pretreatment of lignocellulosic biomass due to the costeffectiveness of ozone generators.

Therefore, the objective of this study was to evaluate the use of ozone pretreatment to facilitate acid hydrolysis and enhance the susceptibility of sugarcane top leaves to hydrolysis. These were then related to the capacity of ozone to increase saccharification and prove the degradation of lignin, hemicellulose and cellulose.

\section{MATERIAL AND METHODS}

\section{A) Plant}

Sugarcane variety 'SP 81-3250' was harvest at the Areão Experimental Station of the Luiz de Queiroz College of Agriculture at the University of São Paulo located in Piracicaba, São Paulo, Brazil ( 22.70 S, 47.63 W, 596 m elevation) during the $2011 / 2012$ season for use in the experiments. Sugarcane top leaves were harvested at cane maturity. Harvested tops were dried at $105 \circ \mathrm{C}$ for twelve hours and finely ground to pass through a 200 mesh using a mill machine (Model TE-651/2,
Tecnal Co., Brazil). The finely ground sugarcane top leaves were stored at room temperature in sealed polypropylene containers prior to use in the experiment.

\section{B) Ozone pretreatments I}

In a batch glass reactor $(1.5 \mathrm{~L})$, finely ground sugarcane top leaves and distilled water were added in a ratio of $24.8 \mathrm{~g}$ of sugarcane top leaves and $1.36 \mathrm{~L}$ of distilled water followed by coupling of the ozone generator (Model HTU 500 AC - Azco Industries Ltd., Langley, Canada) to the top of the glass reactor (Figure 1). The sugarcane top leaves were subjected to two treatments, ozone and water only (control) treatments. The ozone treatment lasted three hours and was divided in three intervals of one hour. The ozone dose was $10.52 \mathrm{mg} \mathrm{O}_{3} \mathrm{~min}^{-1}$ in the first interval; $21.16 \mathrm{mg} \mathrm{O}_{3} \mathrm{~min}^{-1}$ in the second; and 30.69 $\mathrm{mg} \mathrm{O}_{3} \mathrm{~min}^{-1}$ in the third (Table 1). Samples of $50 \mathrm{~mL}$ were collected at the end of each interval for later analysis.

Table 1. Ozone doses used for ozone pretreatment of sugarcane top leaves.

\begin{tabular}{ccc}
\hline Time $(\mathrm{h})$ & $\begin{array}{c}\text { Ozone dose } \\
\left(\mathrm{mg} \mathrm{O}_{3} \mathrm{~min}^{-1}\right)\end{array}$ & $\begin{array}{c}\text { Total dose } \\
\left(\mathrm{mg} \mathrm{O}_{3}\right)\end{array}$ \\
\hline 1 & 10.52 & 631.2 \\
2 & 21.16 & 1269.6 \\
3 & 30.69 & 1841.4 \\
Control & 0.00 & 0.0 \\
\hline
\end{tabular}

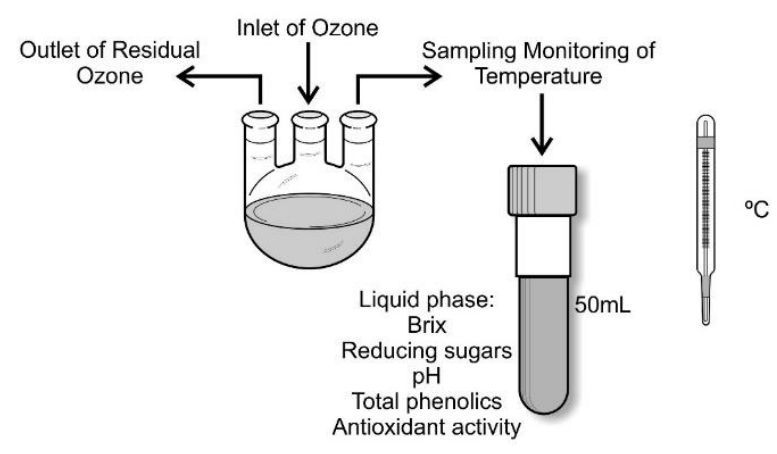

Figure 1. The batch glass reactor.

\section{C) Analysis of the Liquid Fraction}

Soluble solids were measured in Brix scale using a digital portable refractometer (Reichert ${ }^{\mathrm{TM}} \mathrm{AR} 20 \mathrm{O}^{\mathrm{TM}}$, Reichert Instruments $\mathrm{GmbH}$, Seefeld, Germany). ${ }^{11}$ The $\mathrm{pH}$ was determined directly by a digital $\mathrm{pH}$ meter (pH Meter Tec-2, Tecnal Co., Piracicaba, Brazil). Reducing sugars (RS), total phenolics and antioxidant in vitro were measured according to Somogyi-Nelson method, ${ }_{12}^{12}$ Porter, Hrstich and Chan ${ }^{13}$ and Prieto, Pineda and Aguilar, ${ }^{14}$ respectively. Percentage saccharification was then calculated using equation $1::^{15}$ 


$$
\text { Saccharification }=\frac{[R S] \times 0.952}{[C]} \times 100
$$

Where:

\section{Saccharification is expressed as a percentage (\%);}

RS is the concentration of reducing sugar from the supernatant of sugarcane top leaves in $\left(\mathrm{mg} \mathrm{mL}^{-1}\right)$;

Cis the concentration of cellulose in the sugarcane top leaves ( $\mathrm{mg} \mathrm{mL}^{-1}$ ); and

0.952 a conversion factor for cellulose to glucose.

Three replicate measurements were performed for each parameter, and the results were analyzed by Tukey's means separation test at $\alpha=0.05$.

\section{D) Ozone pretreatments II}

It was carried out in $400 \mathrm{~mL}$ Erlenmeyer flasks at $25^{\circ} \mathrm{C}$ with continuous agitation of $100 \mathrm{rpm}$ for three hours. Ozone was added by direct infusion in a suspension of sugarcane top leaves and water at a ratio of $6.54 \mathrm{~g}$ of top leaves and $363.64 \mathrm{~mL}$ of distillated water.

The experimentation was conducted in a full factorial design $2^{3}$. The factors were reaction time in minutes $(x 1)$; concentration of ozone in $\mathrm{mg}$ added in top leaves per minute $(\mathrm{x} 2)$; and $\mathrm{pH}$ of the solution $(x 3)$. The objective was to analyze the interaction among those three variables and their direct effects.

The quantity of trials implemented in this analysis was described by equation 2 :

$$
Q=L^{V}+3
$$

Where:

Q is the number of trials;

L represents the level (two);

V means the quantity of variables (three) and number 3 is the repetition of central point. Thus, there were eleven trials.

After all trials, hemicellulose, lignin and cellulose quantification was done in triplicate. The results was treated by analysis of variance (ANOVA) and multiple regression analysis of response surface methodology, at $\alpha=0.05$, using the software Statistica version 11 (Statsoft, USA).

\section{E) Lignin analysis}

The solid fraction of each trial were oven dried for 12 hours at $105 \circ \mathrm{C}$. The leaves were then milled through a 200 mesh sieve, extracted with ethanol (95\% v.v ${ }^{1}$, Merck, Brazil) using the Soxhlet apparatus, and then hydrolyzed using $72 \%$ $\left(w^{-1} w^{-1}\right)$ sulfuric acid (Sigma-Aldrich, Brazil). The hydrolysate was vacuum filtrated on a porous crucible and the content of insoluble lignin in the retained solid was determined by gravimetry. Soluble lignin in the filtrate was determined by spectrophotometry at $205 \mathrm{~nm} .{ }^{16}$ Then, the filtrate was stored for hemicellulose and cellulose analysis.

\section{F) Hemicellulose and celulose analysis}

The filtrate was extracted at Sep-Pak cartridge $C_{18}$ for removal of aromatic compounds. Then the material was injected directly in the ultrafast liquid chromatography (UFLC) coupled with evaporative light scattering detector (ELSD) for analysis of glucose and xylose. The UFLC/ELSD analysis was performed using a Shimadzu LC-20A chromatography system (Shimadzu Co., Kyoto, Japan), an Aminex HPX-87H column $(300 \times 7.8 \mathrm{~mm})$ at 45 으 (oven temperature) and ELSD Shimadzu LT-II at $80 \circ \mathrm{C}, 350 \mathrm{kPa}$ pressure and gain of 7 . The equipment executed an isocratic run (flow rate $=0.6 \mathrm{~mL} \cdot \mathrm{min}^{-1}$; mobile phase: deionized water). ${ }^{17}$

For determination of acetic acid, the UFLC was coupled with diode array detector (DAD - Shimadzu SPD-M2OA) and performed, using the same column, an isocratic run (mobile phase $\mathrm{H}_{2} \mathrm{SO}_{4} 0.05 \mathrm{~N}$; flow rate $\left.=0.5 \mathrm{mLmin}^{-1}\right) .{ }^{17}$

For furfural and 5-hydroxymethylfurfural (HMF), a VPODS $(5 \mu \mathrm{m})$ column $(250 \times 4.6 \mathrm{~nm})$ with isocratic elution (flow rate $=0.8 \mathrm{~mL} \mathrm{~min}^{-1} ;$ mobile phase: acetonitrile/water $(1 / 8 \mathrm{v.v}$ ${ }^{1}$ ) and acetic acid $1 \%$; flow rate $=0.5 \mathrm{~mL} / \mathrm{min}$ ) at $25 \circ \mathrm{C}$ (oven temperature) using a DAD detector was used. ${ }^{17}$

The concentrations of glucose, xylose, acetic acid, furfural and HMF were estimated using calibration curves of each compound.

The equation 3 and 4 describes how to calculate hemicellulose and cellulose concentration, respectively:

$$
\begin{aligned}
\text { Hemicellulose }= & \left(\frac{\text { yylose }}{\text { TLDW }} \times 0,88\right)+\left(\frac{\text { Furfural }}{T L D W} \times 1,388\right) \\
& +\left(\frac{\text { Acetic acid }}{T L D W} \times 0,7\right)
\end{aligned}
$$

$$
\text { Cellulose }=\left(\frac{\text { Glucose }}{\text { TLDW }} \times 0,9\right)+\left(\frac{5-H M F}{T L D W} \times 1,29\right)
$$

Where:

Hemicellulose and cellulose are expressed in \%;

TLDW is the top leaves dry weight in g; and

Xylose, furfural, acetic acid, glucose and 5-HMF are expressed in $\mathrm{g} . \mathrm{L}^{-1}$ 


\section{RESULTS AND DISCUSSION}

\section{Ozone pretreatments I}

\section{A) Analysis of the liquid fraction}

There were no differences in soluble solids between the ozone and control treatments over a three hour period (Table 2). Also, there were no differences within each treatment over time for soluble solids. Similarly, Madho and Davis $^{18}$ reported no reduction in soluble solids following treatment of sugarcane juice and syrup to remove color. In their study, the syrup and clear juice had 32 and $12 \%(w / w)$ soluble solids, respectively, in other words, normal values for both.

There was no variation in $\mathrm{pH}$ for the control treatment which was 5.5 over a three hour period (Table 2). In contrast, the $\mathrm{pH}$ of the ozone treatment declined from 5.4 to 3.8 at 1 and 3 hours after treatment, respectively. Ozonation on water solutions has been previously reported to have no effect on $\mathrm{pH}$ with the exception of solutions that are alkaline. For example, Díaz et al. ${ }^{19}$ reported that an increase in acidity was observed in ozonated olive (Olea europaea L) and sunflower (Helianthus annuus L.) oils. However, Enami, Hoffmann and Colussi, ${ }^{20}$ reported production of organic acids where the gas-phase ozonation of terpenes yielded several products via a cascade of chemically activated intermediates that ranged from primary ozonides to dioxiranes. According to Ben'ko, Manisova and Lunin $^{21}$ the treatment of lignocellulose substrates with ozone causes lignin destruction and formic, glyoxalic, acetic, oxalic and tartaric acids were found in soluble fraction. Therefore, the ozone dose generated organic acids from lignocellulosic fibers, especially from lignin.

Table 2. Average values after three replications of soluble solids (SS), reducing sugars (RS), $\mathrm{pH}$, antioxidant activity (AA), phenolic total and saccharification (SA) of the liquid fraction over the 3 hours of increasing doses of ozone during pre-treatment.

\begin{tabular}{cccccccc}
\hline \multirow{2}{*}{ Items } & $\begin{array}{c}\text { Time } \\
(\mathrm{h})\end{array}$ & $\begin{array}{c}\mathrm{SS} \\
\text { oBRIX }\end{array}$ & $\begin{array}{c}\mathrm{RS} \\
\left(\mathrm{g} \mathrm{L}^{-1}\right)\end{array}$ & $\mathrm{pH}$ & $\begin{array}{c}\mathrm{AA} \\
\left(\mathrm{mg} \mathrm{mL}^{-1}\right)\end{array}$ & $\begin{array}{c}\text { Phenolic } \\
\left(\mathrm{g} \mathrm{L}^{-1}\right)\end{array}$ & $\begin{array}{c}\text { SA } \\
(\%)\end{array}$ \\
\hline \multirow{4}{*}{ Control } & 1 & $2.0^{\mathrm{a}}$ & $1.46^{\mathrm{c}}$ & $5.5^{\mathrm{a}}$ & $0.188^{\mathrm{a}}$ & $0.42^{\mathrm{a}}$ & $29.18^{\mathrm{c}}$ \\
& 2 & $1.8^{\mathrm{a}}$ & $1.64^{\mathrm{b}}$ & $5.5^{\mathrm{a}}$ & $0.175^{\mathrm{a}}$ & $0.40^{\mathrm{b}}$ & $32.72^{\mathrm{b}}$ \\
& 3 & $1.8^{\mathrm{a}}$ & $1.88^{\mathrm{a}}$ & $5.5^{\mathrm{a}}$ & $0.190^{\mathrm{a}}$ & $0.40^{\mathrm{b}}$ & $37.67^{\mathrm{a}}$ \\
\hline \multirow{3}{*}{ Treatments } & 1 & $1.9^{\mathrm{a}}$ & $1.42^{\mathrm{c}}$ & $5.4^{\mathrm{a}}$ & $0.210^{\mathrm{b}}$ & $0.71^{\mathrm{a}}$ & $28.48^{\mathrm{c}}$ \\
& 2 & $2.0^{\mathrm{a}}$ & $1.88^{\mathrm{b}}$ & $5.2^{\mathrm{b}}$ & $0.255^{\mathrm{a}}$ & $0.70^{\mathrm{a}}$ & $37.55^{\mathrm{b}}$ \\
& 3 & $2.0^{\mathrm{a}}$ & $2.16^{\mathrm{a}}$ & $3.8^{\mathrm{c}}$ & $0.209^{\mathrm{b}}$ & $0.69^{\mathrm{a}}$ & $43.18^{\mathrm{a}}$ \\
\hline
\end{tabular}

The amounts of reducing sugars increased over time for both control and ozone treatments (Table 2). However, reducing sugars increased more after ozone treatment than in control. There was an increase of approximately $51 \%(1.42$ g. $\mathrm{L}^{-1}$ after 1 hour to $2.16 \mathrm{g.L^{-1 }}$ after three hours) in reducing sugar contents in the ozone treatment when compared to an increase of $29 \%$ for the control (1.46 g.L-1 after 1 hour to 1.88 g. $\mathrm{L}^{-1}$ after 3 hours). In the second-generation ethanol, the reducing sugars (or fermentable sugars) are produced from cellulose after the pretreatment and enzymatic or acid saccharification. ${ }^{1}$ The increase of reducing sugars in the control was attributed to diffusion of the released sugars which normally occurs during sample preparation in sugarcane mills. According to Johansson, Lind and Ljunggren ${ }^{22}$ and Lind et al., ${ }^{23}$ cellulose degradation during high consistency ozone bleaching was attributed to free radical chain reactions. Johansson, Lind and Ljunggren ${ }^{22}$ reported that ozonation was suggested as a way to bleach pulp on the basis of its specific and effective reaction with double bonds. However, ozone delignification has been shown to be associated with degradation of pulp cellulose. During pulp production, bleaching by ozonation was negative with regard to cellulose degradation, but this process can be used to produce more quantities of fermentable reducing sugars for bioethanol production. According to those authors, ozonation has the ability to delignify lignocellulosic material, allowing access to cellulose by oxidative processes that can degradate it into fermentable sugars.

The phenolic compounds did not vary over time with in ozone and control treatments; however, phenolic contents were higher for ozone treatments when compared to the control (Table 2). Heinzle et al. ${ }^{24}$ reported low molecular weight of phenolic compounds after treatment of wood pulp with ozone. In addition, they reported that organic acids and other intermediates were initially produced from the phenolics and that liberation of carbon dioxide by decarboxylation or complete oxidation was observed later. The possibility of organic acids release, mainly phenolic acids 
during ozone treatment of sugarcane leaves has been reported by Soares ${ }^{25}$.

There were differences in the levels of antioxidant activity between the ozone and control treatments (Table 2). Levels of antioxidant activity remained constant over time for the control treatment. In contrast, levels of antioxidant activity increased after 2 hours and then decreased (to 1-hour levels) after three hours for the ozone treatment. The ozonated samples showed $10 \%$ higher in vitro antioxidant activity when compared to the control treatment $\left(0,209 \mathrm{mg} \mathrm{mL}^{-1}\right.$ and 0,190 $\mathrm{mg} \cdot \mathrm{mL}^{-1}$, respectively), probably because of more quantities of phenolic compounds released during the ozonation process of the sugarcane leaves.

The sugarcane top leaves susceptibility to hydrolysis was similar to the response of reducing sugars which over time
(Table 2). Saccharification percentage of liquid fraction of the ozone treatment sugarcane top leaves was $28.48,37.55$ and $43.18 \%$ after 1,2 , and 3 hours, respectively. For the control treatment, the levels of saccharification were 29.18, 32.72, and $37.67 \%$ after 1,2 , and 3 hours, respectively.

\section{Ozone pretreatments II}

A) Lignocellulosic analysis

Eleven (11) trials of the full factorial experimental design were evaluated. Table 3 displays the results, including the amounts of cellulose, hemicellulose and lignin in each trial.

Table 3. Coded values and experimental of factorial design matrix $2^{3}$ of aqueous extraction of active compounds top leaves, and the percentage of cellulose, hemicellulose and lignin after each trial.

\begin{tabular}{ccccccc}
\hline Trials & $\mathrm{X}_{1}{ }^{\mathrm{a}}$ & $\mathrm{X}_{2}{ }^{\mathrm{b}}$ & $\mathrm{X}_{3}{ }^{\mathrm{c}}$ & $\begin{array}{c}\text { Cellulose } \\
(\%)\end{array}$ & $\begin{array}{c}\text { Hemicellulose } \\
(\%)\end{array}$ & $\begin{array}{c}\text { Lignin } \\
(\%)\end{array}$ \\
\hline 1 & $-1^{\mathrm{d}}(0)$ & $-1(0)$ & $-1(3)$ & 36.32 & 18.73 & 25.37 \\
2 & $+1^{\mathrm{e}}(60)$ & $-1(0)$ & $-1(3)$ & 33.70 & 15.42 & 27.08 \\
3 & $-1(0)$ & $+1(34.10)$ & $-1(3)$ & 33.51 & 16.21 & 22.31 \\
4 & $+1(60)$ & $+1(34.10)$ & $-1(3)$ & 40.10 & 18.89 & 25.23 \\
5 & $-1(0)$ & $-1(0)$ & $+1(9)$ & 39.42 & 18.73 & 23.46 \\
6 & $+1(60)$ & $-1(0$ & $+1(9)$ & 39.82 & 38.45 & 22.78 \\
7 & $-1(0)$ & $+1(34.10)$ & $+1(9)$ & 38.67 & 20.11 & 24.44 \\
8 & $+1(60)$ & $+1(34.10)$ & $+1(9)$ & 39.25 & 19.78 & 22.26 \\
9 & $0^{f}(30)$ & $0(17.61)$ & $0(6)$ & 39.37 & 19.80 & 23.47 \\
10 & $0(30)$ & $0(17.61)$ & $0(6)$ & 39.43 & 18.93 & 23.61 \\
11 & $0(30)$ & $0(17.61)$ & $0(6)$ & 39.60 & 19.28 & 23.51 \\
\hline
\end{tabular}

${ }^{a} X 1$ is the reaction time in minutes. The standard values are: 0 minute, 30 minutes and 60 minutes.

${ }^{b} \mathrm{X}$ is the concentration of ozone in $\mathrm{mg}$ adder per solvent minute. The standard values are $0.0 \mathrm{mg} / \mathrm{min}, 17.61 \mathrm{mg} / \mathrm{min}$ and $34.10 \mathrm{mg} / \mathrm{min}$.

${ }^{\mathrm{c}} \mathrm{X} 3$ is the $\mathrm{pH}$ of the aqueous extraction The standard values are 3,6 and 9.

${ }^{\mathrm{d}}$ The number 0 represents the central level for each variable.

eThe number +1 represents the maximum levels for each variable.

fThe number -1 represents the minimum level for each variable.

\section{B) Lignin analysis}

The largest main effect at $\alpha=0.05$ was the interaction between time and $\mathrm{pH}$, followed by $\mathrm{pH}$ (linear) and the interaction between ozone dose and $\mathrm{pH}$. The interaction between ozone and time was the only non-significant parameter. Furthermore, pH (linear) and ozone (linear) had a negative effect, indicating that the decrease of both increase the lignin concentration (Figure 2).
The diagram of the response surface (Figure 3) indicates the relationship between $\mathrm{pH}$ and ozone. There were no changes in the lignin concentration regardless of the ozone dose in the $\mathrm{pH}$ range between 6 and 9. However, in the $\mathrm{pH}$ range between 3 and 6, increasing ozone dose resulted in decrease of lignin. In the relationship between $\mathrm{pH}$ and time, lignin concentration varied only at $\mathrm{pH}$ lower than 6 (increase in concentration). In the ozone dose and time diagram, there are no variation in concentration over time. 


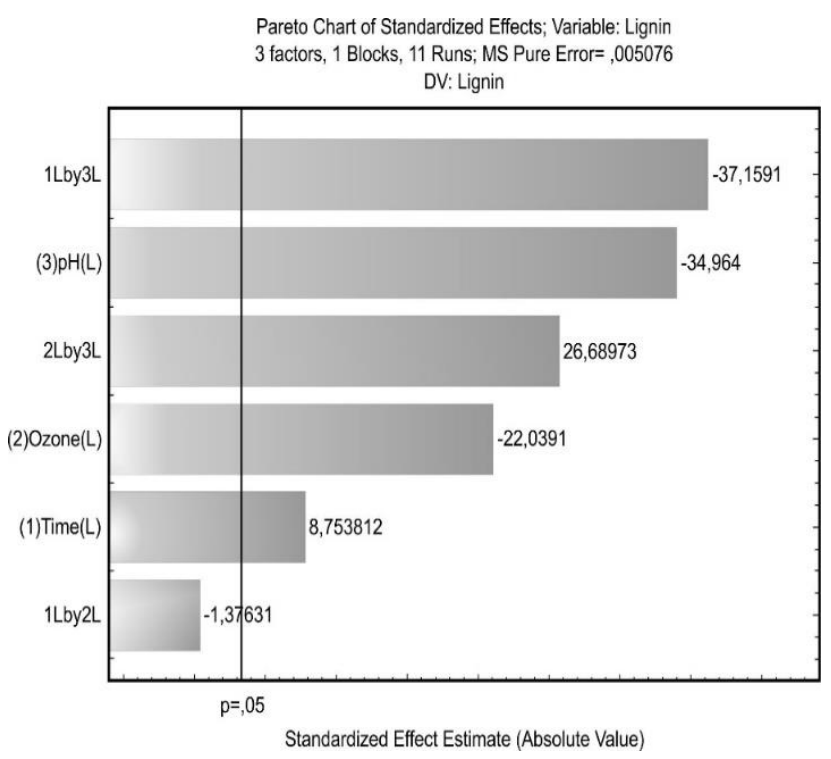

Figure 2. Pareto chart of lignin to estimate the linear effect of time (hour), ozone $\left(\mathrm{mg}^{\mathrm{mL}} \mathrm{mL}^{-1}\right)$, $\mathrm{pH}$ and the interactions between time (hour) and ozone dose (mg. $\mathrm{mL}^{-1}$ ) (1 L by $2 \mathrm{~L}$ ), time (hour) and pH (1L by $3 \mathrm{~L})$, and ozone dose $\left(\mathrm{mg}^{\mathrm{mL}} \mathrm{mL}^{-1}\right.$ ) and $\mathrm{pH}$ ( $2 \mathrm{~L}$ by $\left.3 \mathrm{~L}\right)$.

The analysis of variance (ANOVA) (Table 4) showed that the $R^{2}$ was 0.92213 , this value explained $92.2 \%$ of the variance for lignin concentration. The $F_{\text {model }}$ was significant at $\alpha=0.05$, however, the model was not predictive because the value was not four or five times the $\mathrm{F}$ tabulated, ${ }^{26}$ besides the $F_{\text {model }}$ of lack of fit (161.790) was also significant. A regression analysis was executed to obtain a mathematical equation to describe the relation among lignin (\%), time (hour), ozone dose $\left(\mathrm{mg} \cdot \mathrm{mL}^{-1}\right)$ and $\mathrm{pH}$. The model is described below:

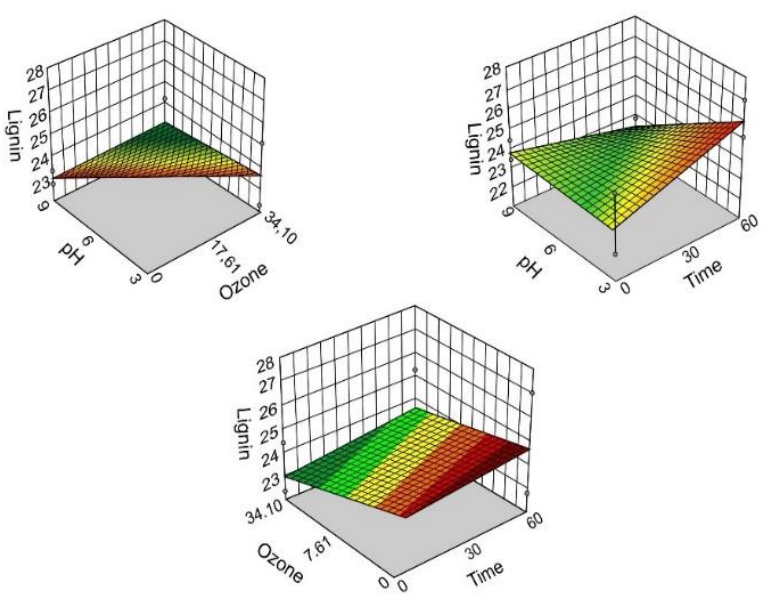

Figure 3. Response surface of lignin for interaction of reaction time in minutes $(x 1)$, concentration of ozone in mg added per solvent per minute $(x 2)$ and $\mathrm{pH}$ of the aqueous extraction $(x 3)$.

$$
\begin{gathered}
\text { Lignin }(\%)=23.96+0.225 A-0.555 B-0.887 C- \\
0.035(A \times B)-0.936(A \times C)+0.672(B \times C)
\end{gathered}
$$

Where:

Lignin was expressed as a percentage (\%);

$\mathbf{A}$ is the time in hours;

B is the ozone dose in $\mathrm{mg} \cdot \mathrm{mL}^{-1}$; and

C is the $\mathrm{pH}$.

\begin{tabular}{|c|c|c|c|c|c|c|}
\hline \multicolumn{7}{|c|}{ Lignin $(\%)=23,96+0,225 A^{a}-0,555 B^{b}-0,887 C^{c}-0,936(A \times C)+0,672(B \times C)$} \\
\hline \multicolumn{7}{|c|}{$R^{2}=0,92213$} \\
\hline Source & Sum of Square & $\begin{array}{l}\text { Degrees of } \\
\text { Freedom }\end{array}$ & $\begin{array}{l}\text { Mean of } \\
\text { Square }\end{array}$ & Fmodel & Ftabulated & $\begin{array}{l}\text { Signif. } \\
\alpha=0.05\end{array}$ \\
\hline Regression & 19.694 & 6 & 3.282 & 7.945 & 6.193 & $*$ \\
\hline Residual & 1.652 & 4 & 0.413 & - & - & - \\
\hline Lack of fit & 1.642 & 3 & 0.821 & 161.790 & 19.000 & $*$ \\
\hline Pure error & 0.010 & 2 & 0.005 & - & - & - \\
\hline Total & 21.347 & 10 & - & - & - & - \\
\hline
\end{tabular}

Table 4. Analysis of variance for the regression model of lignin obtained from the full factorial design.

${ }^{a} A$ - represents time (hour).

${ }^{b} \mathrm{~B}$ - represents ozone dose $\left(\mathrm{mg} \cdot \mathrm{mL}^{-1}\right)$

${ }^{\mathrm{c}} \mathrm{C}$ - represents $\mathrm{pH}$

\section{C) Cellulose analysis}

All parameters were significant at $\alpha=0.05$ and $\mathrm{pH}$ (linear) was the factor that most influences the cellulose concentration (Figure 4). The second was the interaction between time and ozone dose. Beyond that, $\mathrm{pH}$ (linear), time (linear) and ozone dose had a positive effect, so increasing their values, the concentration of cellulose is raised. 


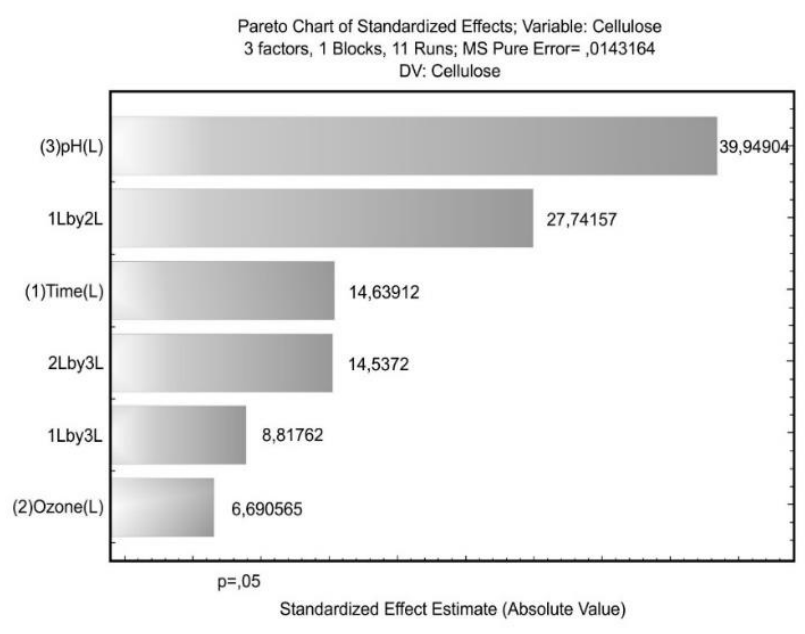

Figure 4. Pareto chart of cellulose to estimate the linear effect of time (hour), ozone (mg.mL-1), $\mathrm{pH}$ and the interactions between time (hour) and ozone dose (mg.mL-1) (1L by $2 \mathrm{~L}$ ), time (hour) and $\mathrm{pH}(1 \mathrm{~L}$ by $3 \mathrm{~L}$ ), and ozone dose (mg.mL-1) and $\mathrm{pH}$ ( $2 \mathrm{~L}$ by $3 \mathrm{~L}$ ).

In the relationship between $\mathrm{pH}$ and ozone, there was no difference in the concentration of cellulose regardless of the ozone dose at $\mathrm{pH}$ above 4 . While at $\mathrm{pH} 3$ the cellulose content increased as the ozone went up. For the relationship of $\mathrm{pH}$ and time, the concentration of cellulose only changed at $\mathrm{pH} 3$ (increased over time). Lastly, in the relationship between ozone dose and time, the cellulose did not change at doses lower than $17.61 \mathrm{mg} / \mathrm{min}$, however the concentration increased over time as the ozone concentration increased. It is noted that a large increase in cellulose content over time when applied at dose of $34.10 \mathrm{mg} / \mathrm{min}$. The cellulose content had an opposite behavior compared with lignin. Thus, the degradation of lignin has apparently led to an increase in the proportion of cellulose in the sugarcane top leaves (Figure 5).

The analysis of variance (ANOVA) (Table 5) showed that the $\mathrm{R}^{2}$ was only 0.70041 , this coefficient explained $70.04 \%$ of the variance for cellulose concentration. The $F_{\text {model }}(1.559)$ was lower than Ftab 6 (6.193), so it was not significant at $\alpha=0.05$. Besides, the $F_{\text {model }}$ lack of fit (622.128) was far from $\mathrm{Ftab}_{2,2}$ and it is significant. Then this model was not adequate to predict the results in that studies, once it was not appropriate for describing the influence of parameters linearly and their relationships.

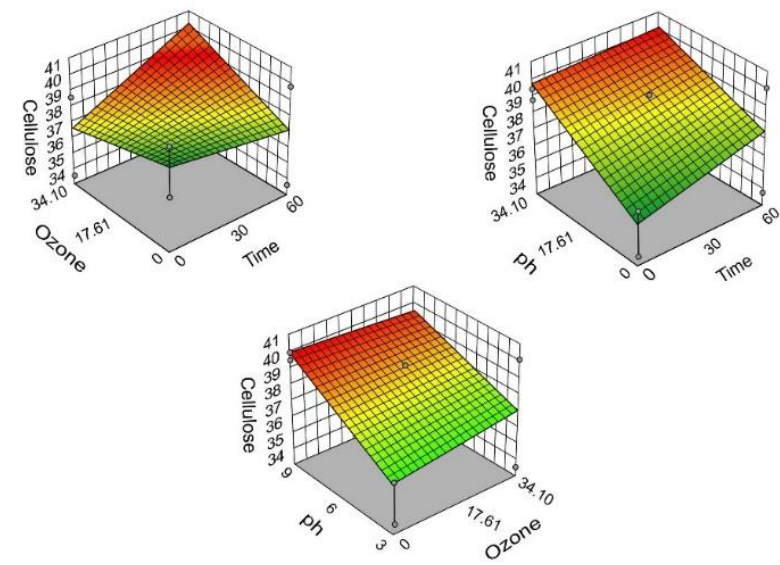

Figure 5. Response surface of cellulose for interaction of reaction time in minutes $(x 1)$, concentration of ozone in mg added per solvent per minute $(x 2)$ and $\mathrm{pH}$ of the aqueous extraction (x3).

Table 5. Analysis of variance for the regression model of cellulose obtained from the full factorial design.

\begin{tabular}{ccccccc}
\hline \multicolumn{1}{c}{$\mathbf{R}^{\mathbf{2}=\mathbf{0 , 7 0 0 4}}$} \\
\hline Source & Sum of Square & $\begin{array}{c}\text { Degrees of } \\
\text { Freedom }\end{array}$ & $\begin{array}{c}\text { Mean of } \\
\text { Square }\end{array}$ & Fmodel & Ftabulated & $\begin{array}{c}\text { Signif. } \\
\alpha=0.05\end{array}$ \\
\hline Regression & 41.713 & 6 & 6.952 & 1.559 & 6.193 & - \\
Residual & 17.842 & 4 & 4.460 & - & - & - \\
Lack of fit & 17.813 & 2 & 8.907 & 622.128 & 19.000 & $*$ \\
Pure error & 0.029 & 2 & 0.014 & - & - & - \\
\hline Total & 59.555 & 10 & - & - & - \\
\hline
\end{tabular}

D) Hemicellulose analysis

First, all parameters are significant at $\alpha=0.05$ (Fig. 6). It was illustrated that $\mathrm{pH}$ (linear) followed by the interaction of time and $\mathrm{pH}$ and time (linear) were the most influential factors. Furthermore, $\mathrm{pH}$ and time had a positive effect on concentration, while ozone dose a negative effect. 


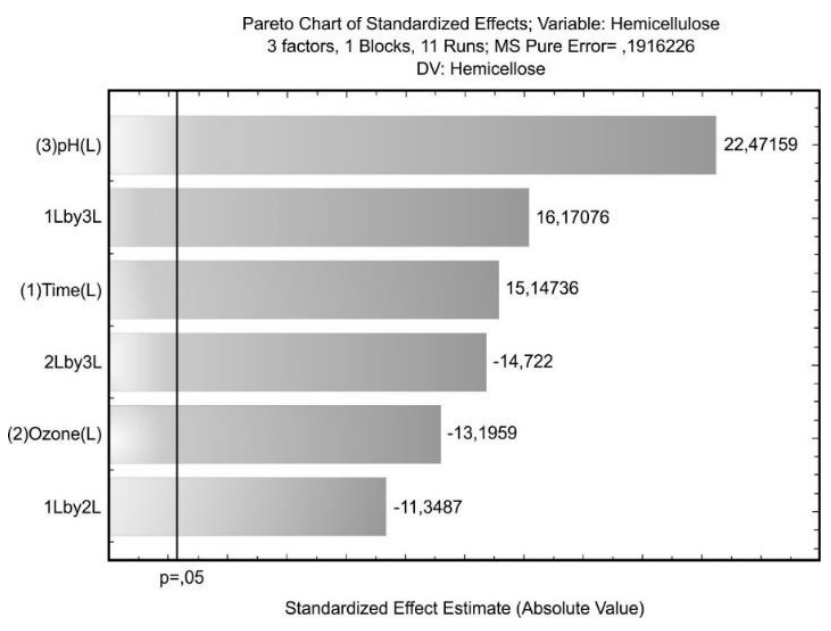

Figure 6. Pareto chart of hemicellulose to estimate the linear effect of time (hour), ozone (mg.mL-1), $\mathrm{pH}$ and the interactions between time (hour) and ozone dose (mg.mL-1) (1L by $2 \mathrm{~L}$ ), time (hour) and $\mathrm{pH}$ ( $1 \mathrm{~L}$ by $3 \mathrm{~L}$ ), and ozone dose (mg.mL-1) and $\mathrm{pH}(2 \mathrm{~L}$ by $3 \mathrm{~L})$.

In the $\mathrm{pH}$ ozone ratio, at $\mathrm{pH}$ lower than 6 there were no differences in hemicellulose concentration regardless of ozone dose. However, at high $\mathrm{pH}$ values $(>6)$, increasing ozone dose led to a drop of hemicellulose. Finally, in the relationship between $\mathrm{pH}$ and time, at low values of $\mathrm{pH}(<6)$, the hemicellulose was constant regardless the time, however above 6 , the concentration increased over time (Figure 7).

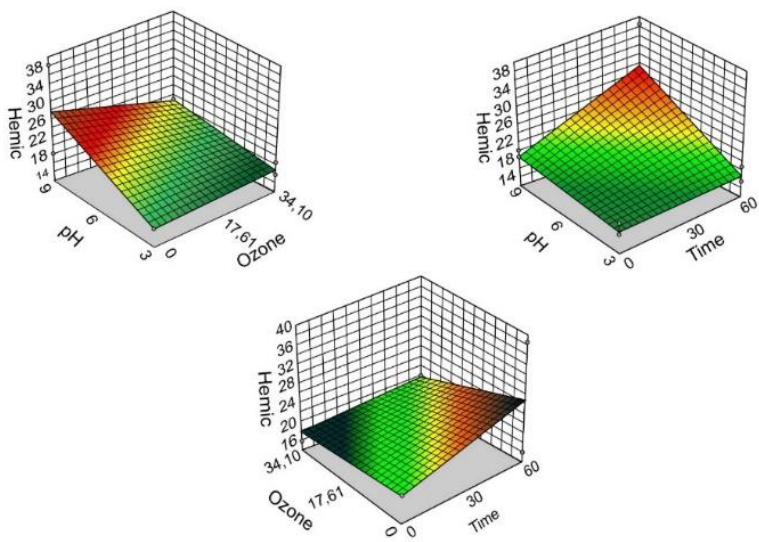

Figure 7. Response surface of hemicellulose (hemic.) for interaction of reaction time in minutes (x1), concentration of ozone in $\mathrm{mg}$ added per solvent per minute $(x 2)$ and $\mathrm{pH}$ of the aqueous extraction $(\mathrm{x} 3)$.

The ANOVA for hemicellulose (Table 6) also shows a low $R^{2}(0.76382)$ and the regression is not significant, once the Regression $F_{\text {model }}(1.559)$ is lower than Ftab $_{6,4}(6.193)$ and the lack of fit $F_{\text {model }}$ (233.14) is higher than $\mathrm{Ftab}_{2,2}$ (19.00). Therefore, the evaluation condition is not adequate to predict the hemicellulose content.

Table 6 - Analysis of variance for the regression model of hemicellulose obtained from the full factorial design.

\begin{tabular}{ccccccc}
\hline Source & Sum of Square & $\begin{array}{c}\text { Degrees of } \\
\text { Freedom }\end{array}$ & $\begin{array}{c}\text { Mean of } \\
\text { Square }\end{array}$ & Fmodel & Ftabulated & $\begin{array}{c}\text { Signif. } \\
\alpha=0.05\end{array}$ \\
\hline Regression & 290.418 & 6 & 48.403 & 2.156 & 6.193 & - \\
Residual & 89.800 & 4 & 22.450 & - & - & - \\
Lack of fit & 89.416 & 2 & 44.709 & 233.314 & 19.000 & $*$ \\
Pure error & 0.383 & 2 & 0.192 & - & - & - \\
\hline Total & 380.217 & 10 & - & - & - & - \\
\hline
\end{tabular}

\section{CONCLUSIONS}

In the condition studied, the ozone was not effective to promote an increbase in total phenolic content and, in consequence, the antioxidant activity did not vary too. On the other hand, the saccharification analysis (cellulose conversion to reducing sugar) showed that the ozone dose used in this work is an alternative for the pretreatment of lignocellulosic materials. In the second treatment, the ozone dose had negative effect to hemicellulose and cellulose concentration and positive effect to lignin.

\section{ACKNOWLEDGEMENTS}

The authors are thankful to their colleagues at NAP/MEPA and ESALQ/USP (Piracicaba, São Paulo, Brazil, Brazil), specially to Dr. F.A.O. Tanaka. 


\section{AUTHOR CONTRIBUITION}

The author Felipe Iwagaki Braga Ogando - Devised and conducted experiments, analysed the results and wrote the paper;

Juliana Aparecida de Souza Sartori and NatháliaTorres Corrêa Magri-Support in the design and conduct;

Claudio Lima de Aguiar - Idealized all experiments, analyzed the results and rewiewed the paper.

\section{COMPETING INTERESTS}

The authors declare there are no competing interests.

\section{FUNDING}

Financial support from FAPESP process (2009/54635-1) and CNPq process (506328/2010-4).

\section{HOW TO CITE THIS ARTICLE}

\section{ABNT}

OGANDO, Felipe et al. Pretreatment of sugarcane top leaves by ozonation as a promotion of susceptibility to hydrolysis. Journal of bioenergy and food science, v.3, n.4, p.197-206, 2016. DOI:10.18067/jbfs.v3i4.119.

\section{APA}

Iwagaki Braga Ogando, F., de Souza Sartori, J., Torres Corrêa Magri, N., \& Lima de Aguiar, C. (2016). Pretreatment of sugarcane top leaves by ozonation as a promotion of susceptibility to hydrolysis. Journal Of Bioenergy And Food Science, 3(4), p.197206. DOI:10.18067/jbfs.v3i4.119

\section{REFERENCES}

(1).AGUIAR, C.L. Biodegradation of the cellulose from sugarcane sugarcane top leaves by fungal cellulase. Ciencia y Tecnologia Alimentaria, v.3, n.2, p.117-121, 2001. DOI:10.1080/11358120109487655

(2).RUBIN, E.M. Genomics of cellulosic biofuels. Nature, v.454, p.841-845, 2008. DOI:10.1038/nature07190

(3).SATHITSUKSANOH, N.; XU, B.; ZHAO, B.; ZHANG, Y.H.P. Overcoming biomass recalcitrance by combining genetically modified switchgrass and cellulose solventbased lignocellulose pretreatment. PLoS ONE, v.8, n.9, e73523, 2013. DOI:10.1371/journal.pone.0073523

(4).ESTEGHALIAN, A.; HASHIMOTO, A.G.; FENSKE, J.J.; PENNER, M.H. Modeling and optimization of the dilutesulfuric-acid pretreatment of corn stover poplar and switchgrass. Bioresource Technology, v.59, n.2-3, p.129136, 1997. DOI:10.1016/S0960-8524(97)81606-9
(5).CHUM, H.L.; JOHNSON, D.K.; BLACK S.; BAKER J.; GROHMANN K.; SARKANEN K.V.; WALLACE, K.; SCHROEDER, H.A. Organosolv pretreatment for enzymatic hydrolysis of poplars: I. enzyme hydrolysis of cellulosic residues. Biotechnology and Bioengineering, v.31, e.7, p.643-649, 1988. DOI:10.1002/bit.260310703

(6).THRING, R.W.; CHORENT, E.; OVEREND, R. Recovery of a solvolytic lignin: effects of spent liquor/acid volume ration, acid concentration and temperature. Biomass, v.23, e.4, p.289-30, 1990. DOI:10.1016/0144-4565(90)90038-L

(7).AZAM, A.M. Pretreatment of cane Sugarcane top leaves with alkaline hydrogen peroxide for enzymatic hydrolysis of cellulose and ethanol fermentation. Journal of Environmental Science and Health, Part B, v.24, n.4, p.421-433, 1989.

(8).VIDAL, P.F.; MOLINIER, J. Ozonolysis of lignin: improvement of invitro digestibility of poplar sawdust. Biomass, v.16, n.1, p.1-17, 1988. DOI:10.1016/01444565(88)90012-1

(9).GARCÍA-CUBERO, M.T.; COCA, M.; BOLADO, S.; GONZÁLEZ-BENITO, G. Chemical oxidation with ozone as pre-treatment of lignocellulosic materials for bioethanol production. Chemical Engineering Transactions, v.21, p.1273-1278, 2010. DOI:10.3303/CET1021213

(10).KOJIMA, Y.; YOON, S.L. Improved enzymatic hydrolysis of waste paper by ozone pretreatment. Journal of Material Cycles and Waste Management, v.10, n.2, p.134-139, 2008. DOI:10.1007/s10163-007-0198-5

(11).MACGILLIVRAY, A.W.; GRAHAM, W.S. Brix determination. Proceedings South Africa Sugar Technology Association, v.6, p.215-218, 1969.

(12).NELSON, N. A photometric adaptation of the Somogyi method for the determination of glucose. Journal of Biological Chemistry, v.153, e.2, p.375-380, 1944.

(13).PORTER, L.J.; HRSTICH, L.N.; CHAN, B.G. The conversion of procyanidins and prodelphinidins to cyanidin and delphinidin. Phytochemistry, v.25, n.1, p.223-230, 1985. DOI:10.1016/S0031-9422(00)94533-3

(14).PRIETO, P.; PINEDA, M.; AGUILAR, M. Spectrophotometric quantitation of antioxidant capacity through the formation of a phosphomolybdenum complex: specific application to the determination of vitamin E. Analytical Biochemestry, v.269, n.2, p.337-341, 1999. DOI:10.1006/abio.1999.4019

(15).TARGONSKI, Z. Alkali process for enhancing susceptibility of auto hydrolyzed beech sawdust to enzymatic hydrolysis. Enzyme and Microbial Technology, v.7, n.3, p.126-185, 1985. DOI:10.1016/0141-0229(85)90142-5

(16).FERRAZ, A.; MENDONÇA, R.; DA SILVA, F.T. Organosolv delignification of white- and brown-rotted Eucalyptus grandis hardwood. Journal of Chemical 
Technology and Biotechnology, v.75, n.1, p.18-24, 2000. DOI:10.1002/(SICI)1097-4660(200001)75:1<18::AIDJCTB169>3.0.CO;2-Z

(17).GOUVEIA, E.R.; NASCIMENTO, R.T.; SOUTO-MAIOR, A.M.; ROCHA, G.J.M. Validação de metodologia para a caracterização química de bagaço de cana-de-açúcar. Química Nova, v.32, n.6, p.1500-1504,2009.DOI:10.1590/S010040422009000600026

(18).MADHO, S.; DAVIS, S.B. Review of proven technologies available for the reduction of raw sugar colour. Proceeding South Africa Sugar Technology Association, v.81, p.165-183, 2008.

(19).DÍAZ, M.F.; HERNÁNDEZ, R.; MARTÍNEZ, G.; VIDAL, G.; GÓMEZ, M.; FERNÁNDEZ, H.; GARCES, R. Comparative study of ozonized olive oil and ozonized sunflower oil. Journal Of The Brazilian Chemical Society, v.17, n.2, p.403-407, 2006. DOI:10.1590/S0103-50532006000200026

(20).ENAMI, S.; HOFFMANN, M.R.; COLUSSI, A.J. Prompt formation of organic acids in pulse ozonation of terpenes on aqueous surfaces. Journal of Physical Chemistry Letters, v.1, n.15, p.2374-2379, 2010. DOI: 10.1021/jz100847a

(21).BEN'KO, M.; MANISOVA, O.R.; LUNIN V.V. Effect of ozonation on the reactivity of lignocellulose substrates in enzymatic hydrolysis to sugars. Russian Journal of
Physical Chemistry A, v.87, n.7, p.1108-1113, 2013. DOI: $10.1134 /$ S0036024413070091

(22).JOHANSSON, E.E.; LIND, J.; LUUNGGREN, S. Aspects of the chemistry of cellulose degradation and the effect of ethylene glycol during ozone delignification of kraft pulps. Journal of Pulp and Paper Science, v.27, n.3, p.239-244, 2000.

(23).LIND, J.; MERENYI, G.; JOHANSSON, E.; BRINCK, T. The reaction of peroxyl radicals with ozone in water. Journal of Physical Chemistry A, v.107, n.5, p.676-681, 2003. DOI: 10.1021/jp026323u

(24).HEINZLE, E.; GEIGER, F.; FAHMY, M.; KUT, O.M. Integrated ozonation-biotreatment of pulp bleaching effluents containing chlorinated phenolic compounds. Biotechnology Progress, v.8, n.1, p.67-77, 1992. DOI: 10.1021/bp00013a010

(25).SOARES, S.E. Ácidos fenólicos como antioxidantes. Revista de Nutrição, v.15, p.71-81, 2002. DOI:10.1590/S1415-52732002000100008

(26).BOX, G.E.P.; HUNTER, W.G.; HUNTER, J.S. Statistics for experimenters: an introduction to design, data analysis and model building. 1 ed. New York: Wiley and Sons, 1978, $653 \mathrm{p}$. 